illness which kept the traveller in his bed for more than two months. Nevertheless the ethnographical collections brought in are very interesting.

THE Smolensky Vestnik gives the following information as to Colonel Prjevalsky. He was born on April 12, 1839, at the village of Otradnoye, in the Smolensk district. His mother and his old nurse, both still alive, were the first who inspired him with a warm love of nature, and his life, on the estate of his mother, contributed to the development of this love. He studied at the Smolensk College (gymnasium), and notwithstanding the desire of his mother, who wished him to enter a university, he entered as a sub-officer in the Polotzk infantry regiment. Promoted to the grade of officer, he went to the military academy, and soon we find him as an officer during the Polish campaign, and afterwards as a teacher of geography and history in the cadet school at Warsaw. A keen hunter, he could not stay long in a city, and he soon undertook a journey to the Oussouri. This determined his ultimate career; the richness of the fauna and the pleasure of hunting in uncivilised countries determined him to undertake further journeys, first to Southern Mongolia, then to Lob-nor, and finally to Tibet, which he reached last year.

UNDER the title of "The Expiring Continent," Mr. A. W. Mitchinson gives an account of his travels in Senegambia, mainly of journeys he made up the rivers Senegal and Gambia. The work contains no dates, thus detracting somewhat from its scientific value, and abounds with speculations and reflections on all sorts of subjects connected with Africa. His notes on what he saw during his journeys are of value as showing the recent condition of the country visited, and, as may be inferred from the title, the author's views are rather desponding. His inference from his observations on the small district visited by him, that the African continent as a whole is "expiring," is far too sweeping. While like the other continents it contains "desert places," the bulk of it, so far as we know it, is capable of the greatest industrial development. That its waters are drying up as a whole there is no reason for believing; but eviłently in this and in other respects there is ample room for trustworthy scientific examination. The publishers are Allen and Co.

THE February number of Petermann's Mittheilungen begins with a paper on the Chukchis on the shores of the Arctic Ocean, their number and present position, based on two articles by $O$. Nordqvist and Lieut. Hovgaard. Dr. Gustav Radde contributes the first part of a narrative of his journey to Talgsch, Aderbeijan, and Sawalan in $1879-80$. From the papers in the North American Review a long account is given of M. Désiré Charnay's explorations of the ruins in Central America. There is an elaborate and detailed map, with accompanying text, illustrating Dr. Junker's journey through the valley of the Chor Baraka, in the Ezyptian province Taka in 1876 .

MessRs. W. AND A. K. Johnston have sent $u_{s}$ the first two parts of a "Statistical Atlas of England, Scotland, and Ireland," by Mr. G. Phillips Bevan. These two parts include Religious and Educational Statistic; and subsequent parts will be devoted to Industry, Crime, Marine, Agricultural, Railways, Geology, and Mining, \&c. ; there will be fifteen parts in all. In the first two parts a vast amount of useful statistics are graphically exhibited on the maps, and systematically arranged in separate tables. Much of the information thus exhibited could not be obtained from any other single source.

No. 90, the coricluding part of the fifteenth volume of the Zeitschrift of the Berlin Geographical Society, contains the conclusion of the late Dr. Erwin von Bay's interesting journal of his journey from Tripoli to Ghât and Air, and a paper on the region which caused the recent contest between Chili and Bolivia, by Dr. C. Marten. The rest of the number, 130 pages, is occupied with the bibliography of the past year, one of the most valuable features of this most important of geographical journals. The bibliography is practically exhaustive, is arranged in a thoroughly systematic manner, and includes works relating to all departments of geography.

M. SIBIRIAKOFF has safely returned to St. Petersburg, where he had a brilliant reception. At a meeting of the Society for the Furtherance of Russian Commercial Navigation, M. Sibiriakoff pointed out the grave errurs contained in Russian marine charts, which caused two of his captains to mistake the Gydan Bay for the Yenisei Estuary. They entered it on September I2, and soon met with thick-packed ice. The Nordland had stopped at once, the Oskar Dickson proceeding some too versts further to the south. Thence the travellers had journeyed to Obdorsk, with Samogedes as guides.

THE Rüppell fund at Frankfort-on-the-Main, which was founded in honour of the Nestor of African travellers, Dr. Eduard Rüppell, and for the exclusive object of supporting scientific exploration, consisted of the sum of 35,570 marks (1770l.) at the end of last year. From this the Senkenberg Naturforschende Gesellschaft, at their last meeting, granted the sum of 3000 marks ( $150 l$ ) ) to Dr. Wilhelm Kobelt of Schwanheim, an eminent conchologist. Dr. Kobelt is now engaged upon the investigation of the existing and fossil molluskan fauna of the Mediterranean, and had during the last few years repeatedly visited Italy and Sicily for this purpose. His next tour, which is to extend from March to September, will comprise Spain, Algeria, and, if possible, Morocco. We may remind our readers that the journeys of Drs. Noll and Grenacher to Spain and the Canary Islands in 1871 , as well as those of Verkrizen to Newfoundland in 1874 and 1875 , were also largely supported by grants from the Riippell fund.

GEODETICAL measurements will be begun next spring on the stretch between Great St. Bernard and the St. Gothard for connecting together the Italian and the Swiss geodetical network.

A NEW expedition will start, next spring, for the exploration of the Obi, under the direction of M. Moiséeff. Six pupils of the Marine School of Arkhangelsk will accompany him.

THERE is some talk of uniting the three geographical societies of Switzerland, those of Berne, Geneva, and St. Gall, as well as those which may be created afterward;, into one great Swiss ge ographical association, which will have a central committee and an anuual general assembly devoted to the study of geographical questions, and especially of those which have a commercial interest.

UNDER the title of "Das Frauenleben der Erde," illustrated by A. von Schweiger-Lerchenfeld, A. Hartleben of Vienna has published a highly interesting description of the social life of the women of all nations. The work contains much that is of ethnographical value, and the numerous well-executed illustrations, as well as the attractive style of the text, are likely to render it of popular interest.

ThE Austrian Section of the German and Austrian Alpine Society held its annual meeting at Vienna, oir January 26 last. The Section now numbers 1302 members.

ON January 29 a branch of the Berlin "Centralverein" for commercial geography was formed at Düsseldorf. The new branch is directing its main attention to South Africa.

In the place of the late Dr. Mook, Dr. Manthey has joined the Riebeck expedition, which will leave Cairo in the course of a few days, and will, first of all, proceed to Socotra by way of Aden.

\section{ABNORMAL VARIATIONS OF BAROMETRIC PRESSURE IN THE TROPICS AND THEIR RELATIONS TO SUN-SPOTS, RAINFALL, AND FAMINES}

M R. F. CHAMBERS, in his valuable and highly interesting article (vol. xxiii. p. 88) under the above title, has made an important step towards placing the relation between secular weather changes and sun-spots on a more substantial basis than it has hitherto occupied. This has been mainly effected by his employing the most reliable data we at present possess of the latter phenomena, thereby bringing the salient features of their minor variations for the first time into direct comparison with a definite meteorological element, which, it may be remarked, possesses the distinct advantage of representing the integrated effect of changes occurring throughout the entire atmospheric envelope.

He has also shown how the remarkable lag which takes place in the occurrence of the critical barometric epochs at the more easterly stations may be utilised to previse famines from a knowledge of what is going on at more westerly ones.

This however would only be practicable if we knew for certain that famines in all the districts mentioned. invariably took their rise from one set of conditions, such as failure of the usual summer rains, preceded and accompanied by high barometric pressure. In attributing the majority of the famines occurring within the tropics to such a proximate cause, Mr. Chambers 
would no doubt be correct; but this relation between pressure and rainfall, strange though the fact may appear, does not apparently hold in the winter in the sub-tropical region of Northern India, nor is famine always caused in this region by a failure of summer rain alone.

For as Mr. S. A. Hill has shown in a paper on "Variations of Rainfall "in Northern India" " Indian Meteorological Memoirs," No. vii. p. 204), a heavy winter rainfall generally coincides with a high barometric pressure over Northern India, and vice versâ, while two of the most severe famines in $\mathrm{Mr}$. Chambers' list, viz., those of $1837-38$ and $1860-61$, in Northern India were caused by "a partial failure of the summer rains, followed by an almost complete absence of the usual winter fall."

It is straining the evidence therefore to attempt to relate these famines, as Mr. Chambers has done, to the previous occurrence of high barometric pressures, since if the law just quoted held good, the famine of $1860-61$ was mainly due to the absence of winter rain, caused by the low pressure which observations show actually existed at that time, and the same was very probably the case in $1837 \cdot 38$, a strongly-marked epoch of sun-spot maximum.

It has moreover been shown by Mr. Hill in the paper just referred to that "the summer rains of the North-West Provinces and Rajpootana have failed quite as often when sun-spots were numerous as when they were few, but whereas in the former case a comparatively slight scarcity has generally been developed into a severe famine through the failure of the winter rains, this has seldom happened in the latter case, the distress at such times being alleviated by the in-gathering of the rabi harvest, rendered more abundant than usual by a copious winter fall." This saving clause with respect to the $w$ inter rainfall of Northern India does not unfortunately apply to Southern India, where failure of the usual monsoon simply means drought and probably famine until the next monsoon, i.e. for an entire year.

On the whole it is plain that high and low atmospheric pressures differ specificalily in their effects in different parts of the Indian peninsula, since while the former is generally a:sociated with drought in the southern provinces, the latter in the winter is almost equally fatal in the northern provinces. If therefore the future prevision of famines is to be based on the empirical law connecting high barometric pressure with the occurrence of drought and famine, propounded by $\mathrm{Mr}$. Chambers, it must be remembered that this law strictly applies only to regions where the annual water-supply is dependent upon the monsoons alone, and therefore lying for the most part between the two tropics.

It niay be remarked that at least half of the Indian peninsula lies north of the tropic of Cancer.

Though I am sceptical as to the idea of motion from west to east, conveyed by the existence of a lag at the more easterly stations, this in no way affects the possibility of prevision as long as the lag remains fairly constant. I am therefore of opinion that in regard to this question the evidence furnished by Mr. Chambers is exceedingly valuable, and that so long as districts are only taken into account that lie within the tropics, such as Southern India, the possibility of prevising famines by noting the occurrence of barometric maxima at more westerly stations may in time be accomplished. For Northern India, and pro. bably other similar sub-tropical regions, the matter is at present more complicated.

E. DOUglas ARCHibald

P.S.-In the preceding letter I have only dwelt upon the limitation to be applied to $\mathrm{Mr}$. Chambers's conclusions in the case of Northern India. It is obvious however that there are at least two distinct difficulties to be explained, before they can be finally accepted, even for countries within the Tropics, viz. (I) Why the barometric waves should commence on one meridian rather than on another, and (2) if, as Mr. Chambers thinks, the waves of pressure travel slowly round the earth, why they do not reappear at the place where they started after an interval of about one year and eight months (calculated from the lags given in Mr. Chambers's paper). At present there does not appear to be the slightest evidence to show that they reappear at all, and if they do not, when and where do they disappear?-E. D. A.

Mr. E. D. ARChibald states in his friendly criticism of my paper on "Abnormal Variations of Barometric Pressure in the Tropics, and their Relations to Sunspots, Rainfall, and Famines," that the occurrence of a decided lag in the barometric movements at easterly, as compared with westerly stations, conld only be utilised to previse famines if we knew for certain that famines in those districts to which the method is applied invariably took their rise from one set of conditions, such as failure of the usual summer rains, preceded and accompanied by high barometric pressure. It appears to me, however, that if the variations of the rainfall can be: definitely related in any manner to the corresponding variations of the barometric pressure, there is no necessity for such a limitation. If, for instance, in Northern India, "a heavy winter rainfall generally coincides with a high barometric pressure, and vice vers $\hat{a}$," as Mr. Archibald seems prepared to admit, then the occurrence in the winter of a high pressure would portend a heavy winter rainfall, and vice versa, and in this case the failure of the winter rains might be foreseen by observing the progress eastward of the barometric minima.

But I am not aware that the relation above mentioned between the barometric pressure and the winter rainfall of Northern India has yet been worked out with sufficient definiteness for the purpose in view, for although there does appear to be some evi dence in favour of that relation when the average pressure and the total rainfall of the whole winter are taken into account, yet on the other hand it is now known that the short rainy feriods of the winter are periods of relatively low pressure. It is not improbable that these periods of low pressure, and the rainfall which acconpanies them, are connected with the feeble cyclonic disturbances which (as appears from the charts of stormtracks published by the American Government) occasicnally enter the north-west of India in the winter months and travel down the Ganges Valley sometimes as far as Bengal. The facts concerning these winter rains seem to accord far better with this view of their origin than with the old notion of their connection with the upper anti-monsoon current, an idea which I observe has now been abandoned by $\mathrm{Mr}$. Blanford, the Meteorolugical Reporter to the Government of India, although up to a recent date it was still retained by some other Indian meteorologists. The question is as yet involved in much obscurity, and I must, with the alove suggestion, leave it to be dealt with by those more immediately concerned.

But whatever the relation between the winter rainfall and the barometric pressure may be, I cannot help thinking that $\mathrm{Mr}$. Archibald attaches an exasgerated relative imporiance to these winter rains, for, from the register of Allahabad, the capital of the province, it appears that the winter rain amounts on the average to only $1.54^{\prime \prime}$, whereas the average summer rain amounts to $36^{\circ} 84^{\prime \prime}$. And similarly at Delhi, the average total winter rain is only $3^{\circ} \mathrm{II}^{\prime \prime}$, while that of the summer is no less than $24^{\circ} 60^{\prime \prime}$. Such being the case, I think it would be difficult to prove that "the famine of $\mathrm{x} 860-6 \mathrm{I}$ in the North-West Provinces was mainly due to the absence of the winter rain," more especially as the summer rain of 1860 in that province was deficient to the extent of nearly one-half, the fall having amounted to only 54 per cent. of the average.

Neither does it seem clear why the methods of forecasting the general character of a coming season, which are suggested in my paper, should of necessity be applicable only to intertiopical regions. It is true that $I$ have dealt only with barometric data furnished by stations lying within the tropics, but my only reacon for doing so was that there seemed a better prospect of obtaining definite results from the records of tropical stations, where the weather is generally of a comparatively settled character, than from those of stations situated in extra-tropical regions, where the weather is generally more disturbed. Indeed I am not without hope that the results I have obtained will induce European meteorologists to take up the subject with a view to the possibility of prevising the general character of coming seasons in Europe from observations recorded in America.

Fred. Chambers

\section{STANDARD THERMOMETERS}

DEAR SIR,-The Kew Committee have instructed me to forward you the enclosed Memorandum on Standard Thermometers, and to request on their behalf that you would be so good as to publish it in NATURE if you consider it suitable for insertion.

Kew Observatory, Richmond, Surrey, February 9

DR. LEONARD WALDO has recently communicated to the American Tournal of Science an article entitled "Papers on Thermometry from the Winchester Observatory of Yale College." 